\title{
POPULATION STRUCTURE AND REPRODUCTION OF THE RAZOR CLAMS Solen lamarckii (Chenu, 1843) IN THE INTERTIDAL ZONE OF API API VILLAGE WATERS, BENGKALIS REGENCY
}

\author{
Rani Fahmia $^{1 *}$, Syafruddin Nasution ${ }^{2}$, Afrizal Tanjung ${ }^{2}$ \\ ${ }^{1}$ Student of the Faculty of Fisheries and Marine Universitas Riau, Pekanbaru \\ ${ }^{2}$ Lecturer at the Faculty of Fisheries and Marine Universitas Riau, Pekanbaru \\ *ranifahmia@gmail.com
}

\begin{abstract}
Razor clam (Solen lamarckii) is a type of pelecypoda that has high economic value on the Api api village waters, Bengkalis Regency. This research aims to study the population structure and reproduction of razor clam. The study was carried out over 2 month period from September to October 2019 at Api api village waters, Bengkalis Regency. Razor clam samples were collected by using a $1 \times 1 \mathrm{~m}^{2}$ frame that laid along transect. There were 5 plots and 5 subplots along the transect as replications. The result showed, the population density of razor clams is 3.12 species $/ \mathrm{m}^{2}$ in September and 2.88 species $/ \mathrm{m}^{2}$ in October 2019. The distribution pattern of razor clams was uniform. While, the most common size of razor clam is the medium size category $(40-60 \mathrm{~mm})$ both in September and in October 2019. The average value of gonado somatic index (GSI) was 2.28-8.60\%. Histological analysis indicated that maturity gonad stage of razor clam was commonly found in September is maturity gonad stage I (60\%), while in October is stage III (40\%) and stage IV(30\%).
\end{abstract}

Keywords: Solen lamarckii, population structure, reproductive aspects, Bengkalis Regency

\section{PENDAHULUAN}

Kerang bambu (S. lamarckii, Chenu 1843) memiliki nama lain Razor Clam, kerang pisau, lorjuk oleh masyarakat Madura dan sepahat oleh masyarakat Melayu. Kerang ini mempunyai bentuk pipih panjang seperti bambu sebesar jari tangan orang dewasa. Kerang ini mempunyai cangkang yang rapuh dan mudah pecah, mempunyai belahan cangkang yang simetris, bentuk memanjang, hampir silindris, terbuka pada kedua ujungnya, dengan pinggiran ventral yang tajam. Pinggiran dorsal dan ventral pararel, dengan tonjolan (umbones) hampir tidak kelihatan dan cangkang bagian dalam halus berwarna putih. Kerang ini merupakan salah satu jenis kerangkerangan yang hidup di laut pada zona intertidal, bersembunyi atau menggali secara vertikal pada sedimen dan akan sedikit keluar pada saat surut (Trisyani dan Nurul, 2008).

Zona intertidal memiliki luas yang sangat terbatas, meliputi wilayah yang terbuka pada saat surut dan terendam pada saat pasang atau separuh waktu ekosistem teresterial dan separuhnya ekosistem akuatik. Walaupun wilayahnya sempit, daerah intertidal memiliki variasi faktor lingkungan terbesar dibandingkan dengan ekosistem lainnya, dan variasi ini dapat terjadi pada daerah yang hanya berjarak dekat. Selain faktor lingkungan, tipe substrat juga bervariasi pada setiap zonanya. Variasi dan dinamika yang ada di zona intertidal akan mempengaruhi keragaman, kepadatan, dan pola sebaran 
organisme yang mendiami zona intertidal tersebut, termasuk salah satu organismenya yaitu kerang bambu.

Seiring dengan peningkatan jumlah penduduk serta terdegradasinya ekosistem pesisir sebagai habitat organisme perairan. maka akan menjadi ancaman bagi kelangsungan hidup kerang bambu terutama pengaruhnya terhadap ketersediaan makanan sebagai salah satu faktor penting dalam menunjang pertumbuhan kerang bambu di perairan. Aktivitas penambangan pasir dan pembuangan limbah rumah tangga masyarakat Desa Api api ke laut akan berdampak terhadap tertekannya habitat kerang bambu di perairan Desa Api api Kabupaten Bengkalis.

Selain itu S. lamarckii atau kerang bambu merupakan jenis kerang-kerangan yang bisa dikonsumsi dan dijual dengan harga tinggi di pasar internasional. Masyarakat di Kabupaten Bengkalis memanfaatkan kerang bambu untuk bahan makanan dan juga dijual kepada konsumen yang ada di Provinsi Riau. Pengambilan kerang bambu secara terus menerus oleh nelayan tanpa mempertimbangkan ukuran dan umurnya diduga akan memberikan dampak pada menurunnya jumlah populasi kerang bambu tersebut di alam. Selain aktivitas penangkapan, menurunnya populasi juga diduga akibat pemangsaan dari organisme lain seperti rajungan yang menjadi predator utama kerang tersebut.

Upaya pelestarian dan manajemen pemanfaatan kerang bambu sangat membutuhkan kajian-kajian mengenai populasi dan pengetahuan biologi reproduksi antara lain studi Indeks Kematangan Gonad (IKG) dan Tingkat Kematangan Gonad (TKG). Indeks kematangan gonad adalah perubahan yang terjadi pada gonad yang dapat dinyatakan secara kuantitatif. Sementara tingkat kematangan gonad adalah tahap-tahap perkembangan gonad sebelum dan sesudah memijah (Effendi, 2002).
Pengetahuan tentang indeks kematangan gonad dan tingkat kematangan gonad merupakan aspek yang sangat penting dalam biologi perikanan, dimana nilai IKG dan TKG digunakan untuk memprediksi kapan organisme tersebut akan siap melakukan pemijahan. Dengan begitu pada saat TKG mencapai tahap matang gonad penangkapan terhadap kerang ini dapat ditekan agar kelestariannya di perairan terus berlangsung terus menerus. Namun sejauh ini belum ada penelitian sebelumnya yang mengkaji mengenai struktur populasi dan reproduksi kerang bambu di perairan Desa Api api Kabupaten Bengkalis.

Untuk informasi yang lebih jelasnya mengenai struktur populasi dan siklus reproduksi kerang bambu yang ada di Desa Api api Kabupaten Bengkalis ini, mendorong penulis untuk melakukan penelitian mengenai Struktur Populasi dan Reproduksi Kerang Bambu (S. lamarckii) di zona intertidal Desa Api api Kabupaten Bengkalis

Tujuan penelitian ini adalah untuk mengetahui kepadatan, pola sebaran dan tingkat kematangan gonad (TKG) kerang bambu yang ada di Perairan Pantai Desa Api api Kabupaten Bengkalis.

\section{METODE PENELITIAN Waktu dan Tempat}

Penelitian ini telah dilaksanakan pada bulan September-Desember 2019. Pengambilan sampel dilakukan di perairan Desa Api api, Kabupaten Bengkalis Provinsi Riau (Gambar 1). Analisis sampel kerang bambu dilakukan di Laboratorium Biologi Laut dan analisis fraksi sedimen dan padatan tersuspensi (TSS) dilakukan di Laboratorium Kimia Laut Fakultas Perikanan dan Kelautan Universitas Riau. Sementara pembuatan preparat histologis untuk analisis Tingkat Kematangan Gonad (TKG) dilakukan di Laboratorium Mikroteknik Jurusan Biologi Fakultas 
Matematika dan Ilmu Pengetahuan Alam Universitas Riau.

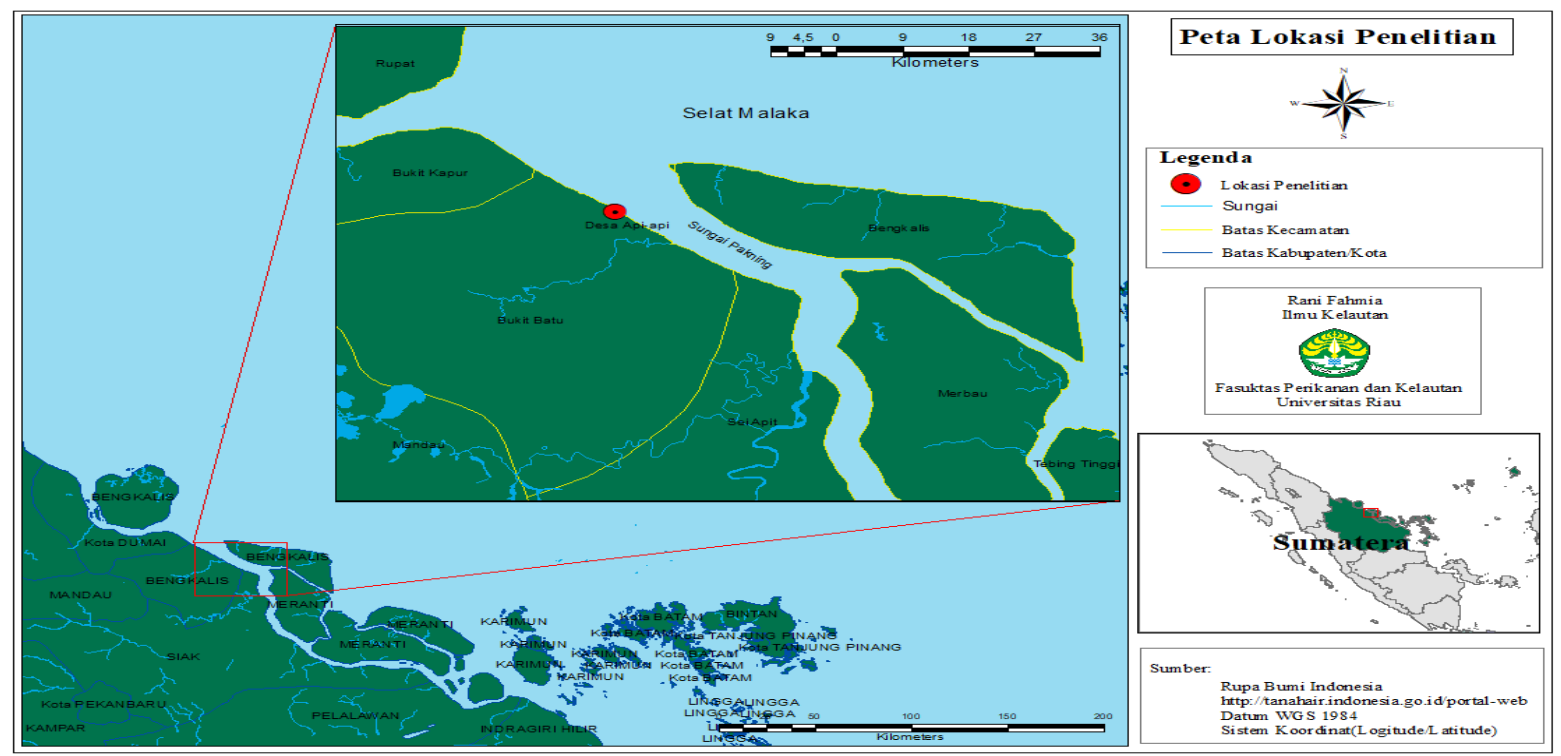

Gambar 1. Peta Lokasi Penelitian

\section{Metode Penelitian}

Metode yang digunakan dalam penelitian ini adalah metode survei. Lokasi penelitian ini ditentukan dengan cara purposive sampling atau dengan mempertimbangkan kondisi dan keadaan daerah penelitian. Daerah penelitian berada di zona intertidal dan dibagi atas lima subzona dengan jarak masing-masing antara subzona \pm 80 meter.

\section{Prosedur Penelitian}

\section{Struktur Populasi}

Sampel kerang bambu diambil di setiap petakan yang berukuran $1 \mathrm{~m}$ x $1 \mathrm{~m}$ di daerah intertidal setelah vegetasi mangrove terluar kearah laut dengan menggunakan sekop kemudian digali hingga kedalaman kira-kira $10-15 \mathrm{~cm}$ dan selanjutnya diayak. Semua individu yang didapat melalui pemungutan tangan dan pengayakan dari substrat dalam plot, dihitung jumlahnya, diukur panjang dan lebar ( $\mathrm{mm})$ menggunakan kaliper serta ditimbang beratnya (g) yang mencakup berat total, berat cangkang, berat soft tissue dan berat gonad menggunakan timbangan analitik. Kemudian perhitungan kepadatan populasi kerang bambu menggunakan rumus Brower et al. (1989) sebagai berikut:

\section{Keterangan:}

\section{$\mathrm{K}=\mathbf{n i} / \mathbf{A}$}

$\mathrm{K}=$ Kepadatan suatu jenis (ind $/ \mathrm{m}^{2}$ )

$\mathrm{ni}=$ Jumlah individu suatu jenis (ind)

$\mathrm{A}=$ Luas area $\left(\mathrm{m}^{2}\right)$

Untuk mengetahui pola distribusi kerang bambu (S. lamarckii) dihitung menggunakan indeks penyebaran Morisita (Brower et al., 1989) sebagai berikut :

Keterangan :

$$
\mathrm{Id}=\left(\mathrm{n}\left(\sum \mathrm{x}^{\wedge} 2\right)-\mathrm{N}\right) /(\mathrm{N}(\mathrm{N}-1))
$$

Id = Indeks penyebaran Morisita

$\mathrm{n} \quad=$ Jumlah plot

$\mathrm{N}=$ Jumlah total individu

$\sum \mathrm{x}^{\wedge} 2=$ Penjumlahan kuadrat individu plot

Hasil penyebaran ini dikelompokkan menjadi 3 kriteria yaitu:
$\mathrm{Id}<1=$ Penyebaran kerang bersifat merata
Id $=1$ = Penyebaran kerang bersifat acak 
Id $>1=\underset{\text { Penyebaran kerang bersifat }}{\text { mengelompok }}$

\section{Indeks Kematangan Gonad}

Analisis indeks kematangan gonad (IKG) dilakukan dengan cara membuka cangkang kerang bambu untuk memisahkan cangkang dan jaringan lunak yang kemudian dilakukan pembedahan dan pemotongan pada jaringan lunak (soft tissue) untuk mengambil gonad berdasarkan ciri-ciri yang terlihat secara morfologi. Kemudian gonad ditimbang menggunakan timbangan analitik dan dilakukan perhitungan Indeks Kematangan Gonad menggunakan rumus (Effendi, 2002) sebagai berikut:

$$
\mathrm{IKG}=\mathrm{BG} / \mathrm{BT} \times 100 \%
$$

Keterangan:

IKG : Indeks Kematangan Gonad (\%)

BG : Berat Gonad (gram)

BT : Berat Tubuh (gram)

\section{Tingkat Kematangan Gonad}

Penentuan tingkat kematangan gonad (TKG) dilakukan melalui pengamatan secara histologis untuk mengetahui perkembangan gonad secara lebih akurat. Sebanyak 20 individu kerang bambu, masing 10 individu perbulan yaitu bulan September dan Oktober 2019, dilakukan pemotongan pada jaringan lunaknya yang terdapat gonad yaitu pada bagian saluran pencernaan ke arah kaki dan kemudian direndam dalam larutan fiksatif yaitu buffer formalin $10 \%$ selama 24 jam.

Selanjutnya didehidrasi dengan alkohol bertingkat dari persentase rendah ke persentase tinggi $(30 \%, 50 \%, 60 \%$, 96\%), dijernihkan dengan xylol dan etanol, diblok dalam paraffin dan dipotong menggunakan mikrotom dengan ketebalan 5 mikron, kemudian diwarnai dengan hematoxylin dan eosin. Preparat histologis diamati dibawah mikroskop dengan perbesaran $10 \mathrm{x}$ 100. Penentuan tingkat kematangan gonad dilakukan dengan berpatokan pada kriteria yang dikemukan oleh Takeuchi et al. (2017).

\section{Kualitas Perairan}

Pengukuran parameter kualitas perairan pada penelitian diukur langsung di lapangan (insitu) pada saat air laut pasang pada masing-masing subzona sebanyak 3 kali pengulangan. Parameter yang diukur yaitu salinitas (ppt), suhu (oC), kecepatan arus $(\mathrm{m} / \mathrm{det})$, kecerahan $(\mathrm{cm})$ dan $\mathrm{pH}$.

\section{Fraksi Sedimen}

Sampel sedimen diambil untuk analisis fraksi sedimen dilakukan dengan 3 kali pengulangan lalu dicampur menjadi satu, menggunakan pipa PVC dengan diameter 2 inchi. Sampel diambil sebanyak 500 gram dari permukaan sampai kedalaman 15-20 cm, kemudian sampel dimasukkan ke dalam kantong plastik dan diberi label sesuai lokasi pengambilan sampel lalu dimasukkan ke dalam ice box untuk selanjutnya dibawa ke Laboratorium Kimia Laut Universitas Riau untuk dianalisis. Analisis butiran sedimen untuk fraksi pasir dan kerikil menggunakan metode pengayakan basah, sementara untuk fraksi lumpur dianalisis dengan metode pipet yang merujuk pada (Rifardi, 2008).

\section{Padatan Tersuspensi (TSS)}

Pengambilan sampel air dilakukan untuk mengetahui jumlah padatan tersuspensi atau TSS (Total Suspended Solid). Sampel air diambil sebanyak 1 liter pada dasar perairan menggunakan botol sampel pada masing-masing subzona dengan 3 kali pengulangan lalu dicampur menjadi 1 .

Analisis padatan Tersuspensi dilakukan memanaskan kertas saring di dalam oven pada suhu $\pm 105^{\circ} \mathrm{C}$ selama 15 menit. Kemudian didinginkan dalam desikator selama 5 menit dan ditimbang segera dengan neraca analitik hingga 
didapatkan berat konstan. Selanjutnya sampel dikocok hingga homogen dan diambil sebanyak $100 \mathrm{ml}$ yang kemudian dilakukan penyaringan menggunakan alat penyaring dan kertas saring. Kemudian kertas saring diambil dengan hati-hati dan diletakkan di atas cawan untuk dipanaskan di dalam oven dengan suhu $105^{\circ} \mathrm{C}$ selama 2 jam. Selanjutnya didinginkan dalam desikator dan ditimbang segera dengan neraca analitik hingga diperoleh berat konstan. Untuk mengetahui jumlah total padatan tersuspensi dilakukan perhitungan dengan rumus :

Keterangan :

$$
\mathrm{TSS}=\frac{(A-B) \times 1000}{V}
$$

$$
\begin{aligned}
\mathrm{A}= & \text { Berat filter dan residu sesudah } \\
& \text { pemanasan }(\mathrm{g}) \\
\mathrm{B}= & \text { Berat kertas saring kosong }(\mathrm{g}) \\
\mathrm{V} & =\text { Volume sampel }(\mathrm{l})
\end{aligned}
$$

\section{HASIL DAN PEMBAHASAN Kondisi Umum}

Desa Api api yang merupakan lokasi penelitian masuk kedalam wilayah Kecamatan Bandar Laksmana Kabupaten Bengkalis Provinsi Riau. Secara geografis Kecamatan Bandar Laksmana bersebelahan dengan Kecamatan Bukit Batu. Luas wilayah Kecamatan Bandar Laksmana adalah $640 \mathrm{~km}^{2}$. Kecamatan ini terdiri dari 7 desa dengan desa terluas yaitu Tenggayun seluas $145 \mathrm{~km}^{2}$, dan yang terkecil yaitu desa Tanjung Leban dengan luas 20,4 km² atau sebesar $8.16 \%$ dari luas keseluruhan kecamatan Bandar Laksmana. Kecamatan Bandar Laksmana memiliki jumlah penduduk lebih kurang 33.739 jiwa, yang terdiri dari 17.171 jiwa adalah laki-laki dan 16.586 jiwa adalah perempuan (BPS Kabupaten Bengkalis, 2017).

Desa Api api merupakan daerah dataran rendah dengan ketinggian lereng rata-rata 2-6,1 $\mathrm{m}$ dari permukaan laut. Sebagian besar merupakan tanah organosol yang banyak mengandung bahan organik. Desa Api api mempunyai iklim tropis dengan temperatur $26-32^{\circ} \mathrm{C}$ serta musim hujan biasanya terjadi sekitar bulan September hingga Januari dengan curah hujan rata-rata berkisar antara 809-4.078 $\mathrm{mm} /$ tahun. Sementara musim kemarau biasanya terjadi antara bulan Februari hingga Agustus (BPS Kabupaten Bengkalis, 2017).

Pantai yang terletak di Desa Api api mempunyai bentuk landai yang berhadapan langsung dengan perairan Selat Malaka. Pantai ini umumnya ditumbuhi oleh vegetasi hutan mangrove yang dikelola oleh desa. Hutan mangrove ini membentang sepanjang pantai hingga jarak yang cukup jauh. Substrat di pantai ini sendiri adalah jenis substrat pasir berlumpur yang umumnya dijumpai pada daerah wilayah Provinsi Riau. Hal ini dikarenakan arus yang terdapat di perairan ini tergolong lemah sehingga hanya mampu menggerakkan partikel yang berukuran kecil. Selain itu perairan Desa Api api tergolong keruh yang disebabkan oleh kandungan lumpur yang tergolong tinggi yang berasal dari vegetasi hutan mangrove (Inggriyani, 2017).

\section{Kepadatan Kerang Bambu}

Kepadatan adalah hasil bagi jumlah individu terhadap luasan areal pengamatan. Pentingnya mengamati kepadatan kerang adalah untuk mengetahui tingkat kehidupan, apakah berada pada kondisi stabil atau terancam. Kepadatan kerang sangat berkaitan dengan bahan organik dan jenis subtrat. Hal ini karena bahan organik dan jenis substrat merupakan bahan makanan yang sangat penting untuk organisme kerang serta habitat bagi organisme. Hasil perhitungan kepadatan kerang bambu diketahui bahwa rata-rata kepadatan kerang bambu di pantai Desa Api api adalah sebesar $3,12 \mathrm{ind} / \mathrm{m}^{2}$ pada bulan September dan 2,88 ind $/ \mathrm{m}^{2}$ pada bulan Oktober 2019. Hasil pengukuran kepadataan kerang bambu pada setiap 
subzona penelitian dapat dilihat pada Gambar 2.

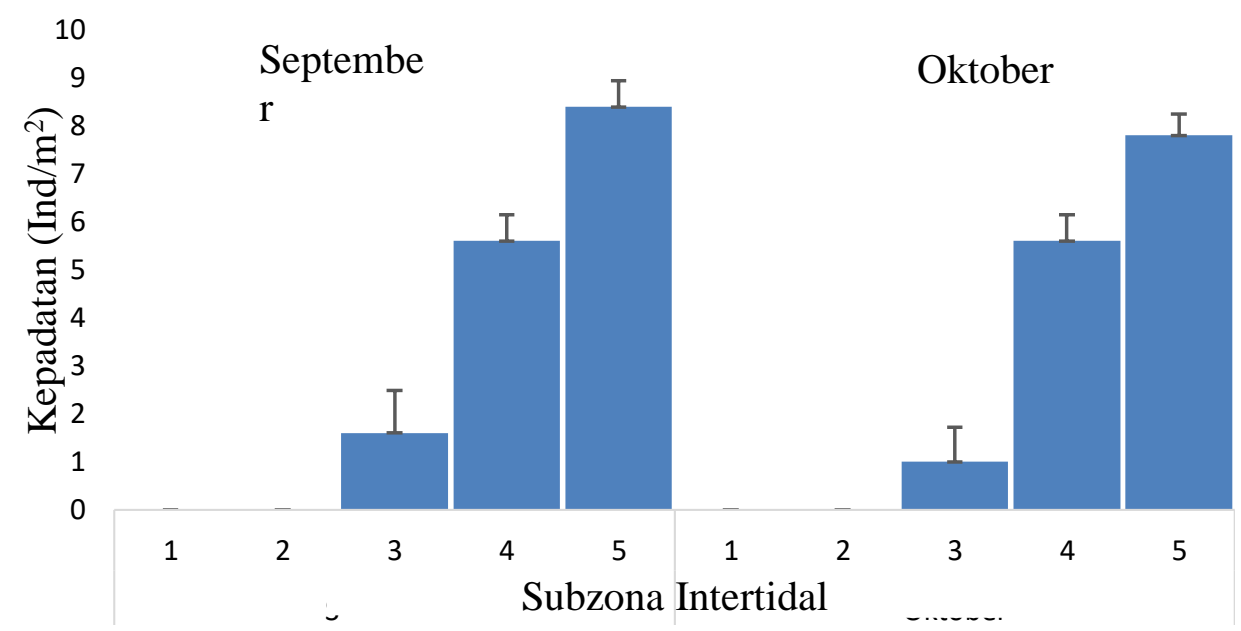

Gambar 2. Kepadatan Kerang Bambu (S. lamarckii) pada Tiap subzona di Zona Intertidal Perairan Pantai Desa Api api pada Bulan September-Oktober 2019.

Pada Gambar 2 dapat dilihat bahwa kepadatan tertinggi terdapat pada subzona 5 yaitu yang berada pada wilayah garis ratarata surut atau yang berhadapan langsung dengan laut, sementara kepadatan terendah terdapat pada subzona 1 dan 2 yaitu zona intertidal yang dekat dengan garis rata-rata pasang yang tidak ditemukan spesies kerang bambu.

Kerang bambu mulai ditemukan pada jarak \pm 160 meter dari vegetasi mangrove terluar, yaitu subzona 3 sampai subzona 5 . Hal ini dikarenakan pada subzona 1 dan subzona 2 terekspos lebih lama pada saat terjadi surut sebelum terjadinya pasang. Sementara subzona 3 sampai subzona 5 berada di daerah surut terendah sehingga plot tersebut lebih lama terendam air laut. Selain itu pada subzona 1 dan subzona 2 memiliki jenis substrat yang banyak mengandung lumpur dengan konsentrasi pasir $50,65 \%$ dan lumpur $49,35 \%$ pada subzona 1 , begitu juga pada subzona 2 ditemukan $52,50 \%$ pasir dan $47,50 \%$ lumpur. Hal ini sesuai dengan penelitian yang dilakukan oleh Subiyanto et al. (2013) kerang bambu menyukai jenis sustrat pasir berlumpur dengan persentase pasir antara $70-95 \%$ dan lumpur 5-30\%.

\section{Pola Distribusi}

Penyebaran populasi yang merupakan penyebaran individu memiliki tiga pola dasar yaitu acak (random), seragam/merata (uniform) dan mengelompok (clumped). Pola sebaran kerang bambu dapat dilihat pada Tabel 1 .

Tabel 1. Pola Distribusi Kerang Bambu (S. lamarckii) pada Tiap Subzona di Zona Intertidal Perairan Pantai Desa Api api.

\begin{tabular}{lcccc}
\hline \multirow{2}{*}{ Subzona/Jarak } & \multicolumn{2}{c}{ September } & \multicolumn{2}{c}{ Oktober } \\
\cline { 2 - 5 } & $\begin{array}{c}\text { Indeks Distribusi } \\
\text { Morisita }\end{array}$ & $\begin{array}{c}\text { Pola } \\
\text { Distribusi }\end{array}$ & $\begin{array}{c}\text { Indeks Distribusi } \\
\text { Morisita }\end{array}$ & Pola Distribusi \\
\hline $1(0 \mathrm{~m})$ & - & - & - & - \\
$2( \pm 80 \mathrm{~m})$ & - & - & - & - \\
$3( \pm 160 \mathrm{~m})$ & 0,54 & Merata & 0,50 & Merata \\
$4( \pm 240 \mathrm{~m})$ & 0,86 & Merata & 0,86 & Merata \\
$5( \pm 320 \mathrm{~m})$ & 0,96 & Merata & 0,96 & Merata \\
\hline
\end{tabular}


Pada Tabel 2 dapat dilihat bahwa sebaran kerang bambu bersifat merata (Id $<1)$ pada masing-masing subzona penelitian. Pola sebaran yang merata/seragam terjadi apabila ada persaingan yang keras sehingga timbul kompetisis yang mendorong pembagian ruang yang sama. Faktor fisika dan kimia yang hampir merata pada suatu habitat serta tersedianya makanan bagi hewan yang hidup di dalamnya sangat menentukan hewan tersebut hidup berkelompok, acak, maupun normal.

\section{Distribusi Frekuensi Ukuran}

Hasil pengukuran individu kerang bambu yang diperoleh pada bulan September berkisar antara 19,89-69,77 mm sementara pada bulan Oktober berkisar antara 32,37- 80,06 $\mathrm{mm}$ yang dapat dikelompokkan menjadi tiga kelas ukuran, yaitu besar (> $61 \mathrm{~mm})$, sedang $(40-60 \mathrm{~mm})$, dan kecil $(<39 \mathrm{~mm})$ mengacu pada hasil sampel yang didapatkan. Jumlah individu pada setiap kelompok ukuran dapat dilihat pada Gambar 3.

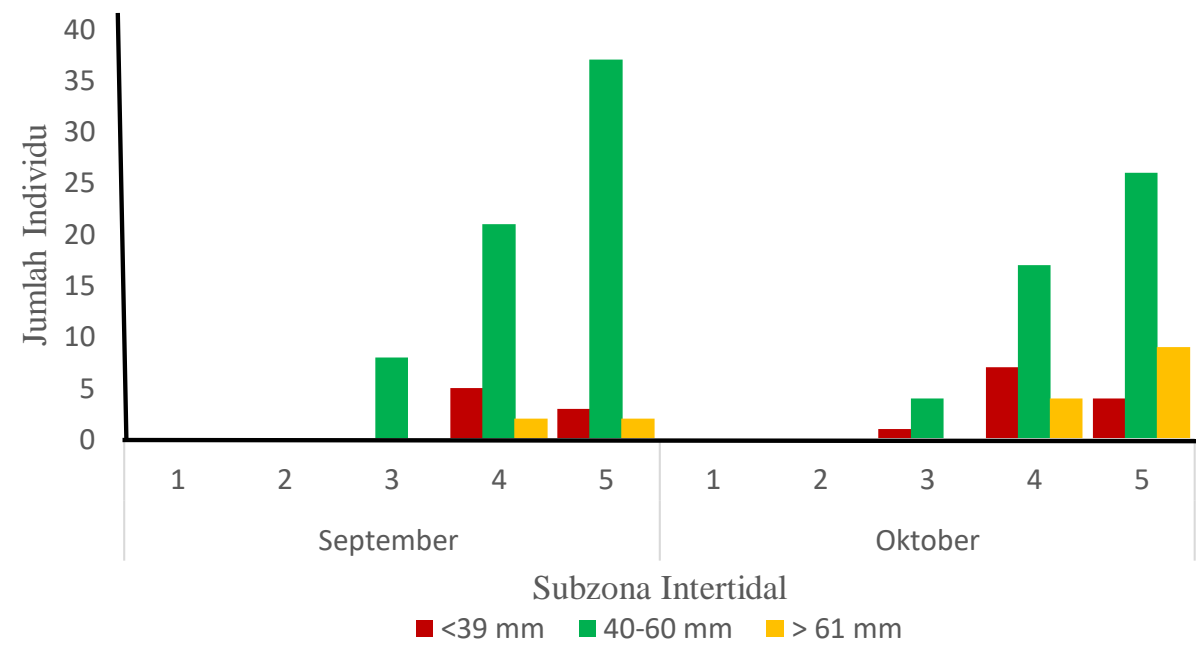

Gambar 3. Jumlah Individu Kerang Bambu (S. lamarckii) Berdasarkan Kelompok Ukuran Pada Masing-Masing Subzona di Zona Intertidal pada Bulan SeptemberOktober 2019

Kerang bambu yang ditemukan pada penelitian di perairan pantai Desa Api api memiliki ukuran antara 19,89-68,71 mm pada bulan September dan 32,37-80,06 mm pada bulan Oktober 2019. Hal ini menunjukkan kerang bambu mengalami pertumbuhan panjang. Pada bulan September ukuran kerang bambu yang ditemukan lebih kecil dibandingkan pada bulan Oktober dan banyak yang masih dalam tahap anakan. Namun jumlahnya lebih banyak yaitu 78 individu dibandingkan bulan Oktober sebanyak 72 individu. Hal ini dikarenakan populasi yang didominasi oleh kelompok individu muda menunjukkan populasi yang sedang berkembang, sementara populasi yang berukuran besar atau populasi yang terdiri dari kelompok umur tua menunjukkan pertumbuhan dari populasi. Populasi yang terdiri dari sebagian kelompok umur tua menunjukkan populasi yang sudah menurun salah satu penyebabnya yaitu mortalitas (kematian) baik secara alami atau karena predasi.

\section{Indeks Kematangan Gonad}

Indeks Kematangan Gonad (IKG) merupakan tanda untuk membedakan kematangan gonad berdasarkan berat gonad dan secara alami berhubungan dengan ukuran dan berat tubuh (Octavina, 2014). 
Indeks ini dinamakan juga Gonado Somatic Indeks (GSI) yaitu suatu nilai yang dinyatakan dalam persen sebagai hasil dari perbandingan berat gonad dengan berat tubuh dikalikan $100 \%$. Nilai rata-rata indeks kematangan gonad kerang bambu yang diperoleh tiap petakan berkisar antara $2,88 \%-3,77 \%$ pada bulan September dan
7,39-8,60\% pada bulan Oktober 2019. Ini menunjukkan bahwa nilai indeks kematangan gonad mengalami peningkatan pada bulan Oktober. Peningkatan nilai indeks diartikan sebagai awal kematangan gonad dan penurunan drastis nilai indeks mengindikasikan terjadinya pemijahan (Sereflisan et al., 2013).

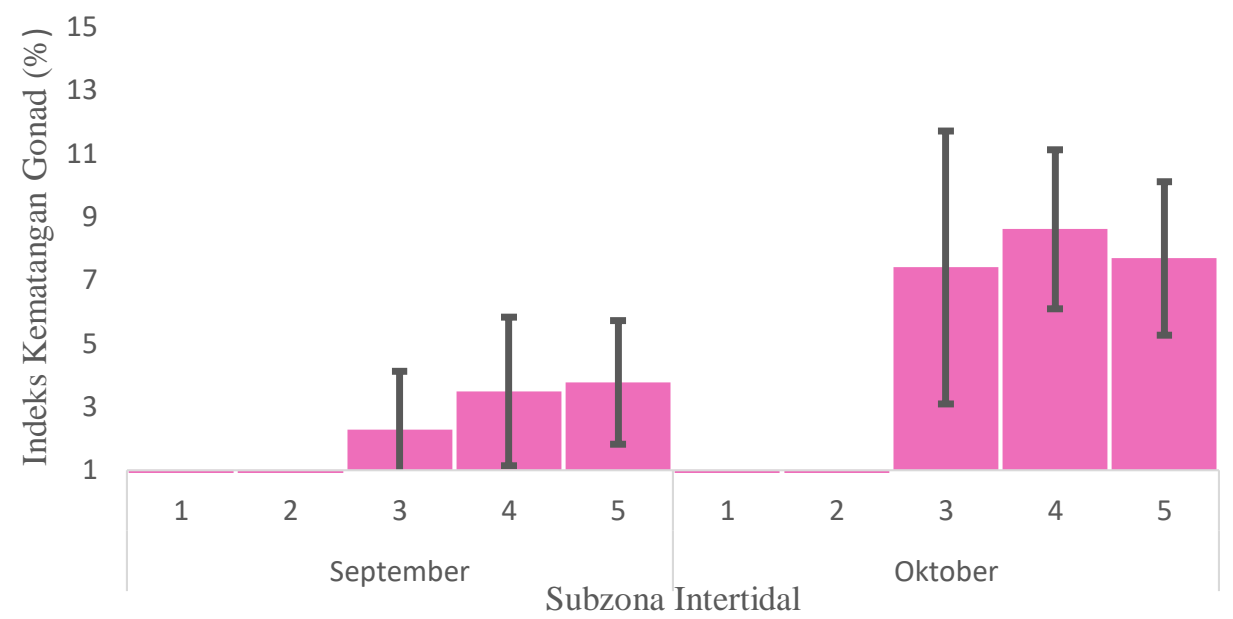

Gambar 4. Nilai Rata-rata Indeks Kematangan Gonad Kerang Bambu (S. lamarckii) pada Tiap Subzona di Zona Intertidal Perairan Pantai Desa Api api September dan Oktober 2019

Nilai indeks kematangan gonad mengalami perubahan seiring perubahan Tingkat Kematangan Gonad (TKG) dan mencapai puncak sesaat akan memijah, sehingga Indeks Kematangan Gonad (IKG) dapat digunakan untuk mengetahui musim pemijahan. Hal ini sesuai dengan pernyataan Efriyeldi et al. (2012), nilai indeks kematangan gonad dari setiap bulan akan berbeda-beda, sesuai dengan besarnya fekunditas serta besarnya diameter telur dari suatu kerang, semakin besar fekunditas dan diameter telur suatu kerang. maka semakin besar nilai Indeks Kematangan Gonad (IKG) dari kerang tersebut.

\section{Tingkat Kematangan Gonad}

Hasil pengamatan

tahap perkembangan gonad selama penelitian terhadap 20 sampel (preparat histologis) yang mengacu pada tahapan yang dikemukakan Takeuchi et al. (2017) didapatkan tahap perkembangan gonad kerang bambu sebanyak lima tahapan, yaitu istirahat (resting), pembelahan (gametogenesis), matang (ripe), pemijahan (spawning), dan sudah dikeluarkan sebagian (partially spawned) (Tabel 2 dan 3) 
Tabel 2. Tingkat Kematangan Gonad (TKG) kerang bambu betina (S. lamarckii)

\begin{tabular}{|c|c|}
\hline Tahap Perkembangan Gonad Kerang Betina & Deskripsi \\
\hline 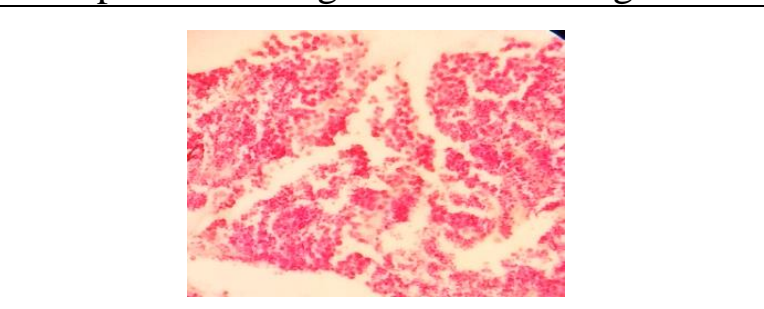 & $\begin{array}{l}\text { Fase } 0 \text {, Fase Istirahat (Resting) } \\
\text { - Jaringan folikel sangat tipis } \\
\text { - Belum terjadi pembelahan gamet. } \\
\text { - Banyak terdapat jaringan ikat }\end{array}$ \\
\hline & $\begin{array}{l}\text { Fase I, Pembelahan (Gametogenesis) } \\
\text { - Meningkatnya ukuran folikel } \\
\text { - Terdapat oosit primer. }\end{array}$ \\
\hline & $\begin{array}{l}\text { Fase II, Matang Gonad (Ripe) } \\
\text { - Folikel mengandung oosit yang } \\
\text { matang } \\
\text { - Dinding folikel tipis }\end{array}$ \\
\hline & $\begin{array}{l}\text { Fase III, Pemijahan (Spawning) } \\
\text { - Folikel-folikel kehilangan strukturnya } \\
\text { - Mengandung oosit yang matang }\end{array}$ \\
\hline & $\begin{array}{l}\text { Fase IV, Dikeluarkan sebagian (Spent) } \\
\text { - Folikel mengalami penyusutan } \\
\text { - Sebagian besar kosong, sangat sedikit } \\
\text { oogonia dijumpai. }\end{array}$ \\
\hline
\end{tabular}


Tabel 3. Tingkat Kematangan Gonad (TKG) kerang bambu jantan (S. lamarckii)

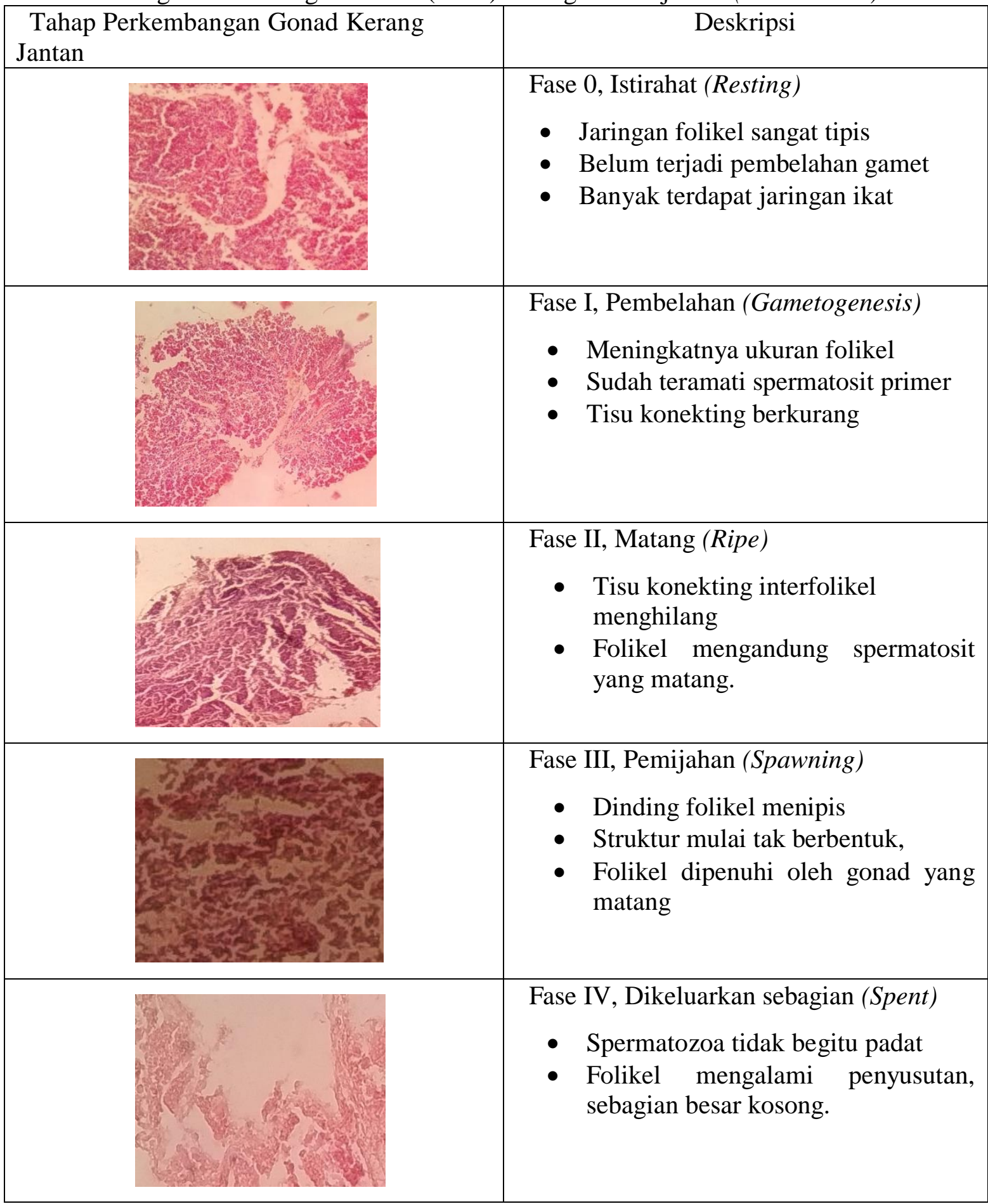

Tingkat Kematangan Gonad diperlukan untuk menunjukkan suatu tingkat kematangan seksual serta menunjukkan kapan kerang bambu akan memijah. Semakin berkembang gonad, telur yang terkandung di dalamnya semakin besar garis tengahnya sebagai hasil pengendapan telur, hidrasi dan pembentukan butir-butir minyak berjalan secara bertahap terliput dalam perkembangan tingkat kematangan gonad mencerminkan pola pemijahan spesies yang ada (Effendie 2007). Menurut Guilbert (2007) menyatakan bahwa tingkat 
kematangan gonad ditentukan berdasarkan kualitas luasan gonad yang menutupi dinding visceral mass. Jika luasan daerah hampir menutupi visceral mass maka individu tersebut memiliki tingkat kematangan gonad yang lebih tinggi dibandingkan individu yang memiliki luasan daerah gonad yang sempit, (Wahyuningtyas 2010).

Pada preparat histologis yang diamati pada masing-masing bulan selama penelitian (Gambar 5) dapat diketahui tingkat kematangan gonad pada bulan
September tahap TKG yang paling banyak adalah tahap 1 (gametogenesis) yaitu 6 individu, yang terdiri dari 3 jantan dan 3 betina. Kemudian yang paling sedikit adalah tahap 0 dan II (matang gonad) yaitu masing-masing sebanyak 2 individu. Sementara pada bulan Oktober tahap TKG yang paling banyak adalah tahap III (pemijahan) yaitu 5 individu terdiri dari 2 jantan dan 3 betina. Kemudian yang paling sedikit tahap I dan II (Matang gonad) yaitu masing-masing 1 individu.

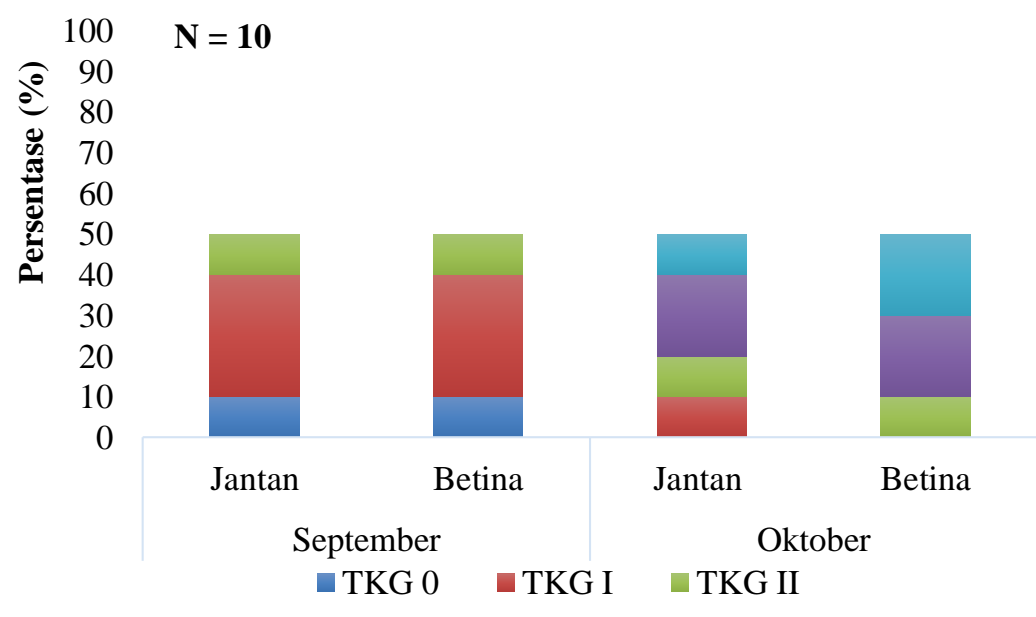

Gambar 5.Tingkat Kematangan Gonad Kerang Bambu (S. lamarckii) di Zona Intertidal Perairan Desa Api api pada Bulan September-Oktober 2019.

Proses kematangan gonad diduga dipengaruhi oleh faktor-faktor lingkungan seperti suhu, makanan dan bahan organik. Hal ini sesuai dengan pernyataan Fujaya dan Yushinta (2004) bahwa, faktor-faktor lingkungan seperti suhu, salinitas, arus dan ketersediaan makanan dapat mempengaruhi saat spesies pertama kali matang gonad. Menurut Litaay (2014) menyatakan bahwa suhu merupakan faktor pembatas bagi beberapa fungsi biologis hewan air seperti migrasi, pemijahan, efisiensi makanan, kecepatan proses perkembangan embrio serta kecepatan metabolisme

Organisme perairan yang hidup di daerah tropis mempunyai kebiasaan memijah sepanjang tahun. Efriyeldi et al. (2012) menyatakan bahwa kerang di derah tropis memijah sepanjang tahun dengan terlihatnya stadium pemijahan pada setiap bulan. Hal ini karena kondisi suhu perairan yang relatif sama dan kondisi biologis perairan yang tidak bervariasi. Oleh karena ditemukannya kerang bambu yang matang gonad setiap bulan dapat dinyatakan bahwa kerang bambu yang hidup di pesisir Desa Api api memijah sepanjang tahun dan memperlihatkan adanya peningkatan jumlah individu yang matang gonad pada bulan Oktober.

\section{Parameter Kualitas Perairan}

Lingkungan laut dan pesisir selalu berubah atau dinamik. Kadang-kadang perubahan lingkungan ini terjadi secara cepat ataupun lambat. Cepat atau 
lambatnya perubahan tersebut akan mengubah intensitas faktor-faktor lingkungan yang akan mempengaruhi pula termasuk kerang bambu. Hasil pengukuran kualitas perairan dapat dilihat pada Tabel kehidupan makhluk hidup didalamnya 4.

Tabel 4. Parameter Kualitas Perairan pada Masing-Masing Subzona Penelitian.

\begin{tabular}{llllllllllll}
\hline & \multicolumn{1}{c}{ Subzona } \\
\cline { 2 - 11 } & \multicolumn{1}{c}{ Parameter } & 1 & 2 & 3 & 4 & 5 & 1 & 2 & 3 & 4 & 5 \\
\hline Suhu $\left({ }^{\circ} \mathrm{C}\right)$ & 27 & 27 & 27 & 27.60 & 28 & 27 & 27 & 27 & 28 & 28 \\
Salinitas (ppt) & & & & & & & & & & \\
Ph & 26 & 26,60 & 27 & 28,30 & 29 & 26 & 27 & 27 & 28,60 & 29 \\
Kecerahan (cm) & 6,30 & 6,60 & 7 & 7 & 7 & 6,30 & 7 & 7 & 7 & 7 \\
& 17,30 & 20,30 & 23 & 29,60 & 35,30 & 18 & 20 & 23 & 29,30 & 35,30 \\
Kec. arus (m/det) & 0,03 & 0,03 & 0,04 & 0,04 & 0,04 & 0,03 & 0,04 & 0,04 & 0,04 & 0,04 \\
\hline
\end{tabular}

Hasil parameter lingkungan menunjukkan kisaran yang cukup baik untuk pertumbuhan dan distribusi $S$. lamarckii, yaitu temperatur air berkisar antara $27-28^{0} \mathrm{C}$, $\mathrm{pH}$ antara 6,3-7, salinitas antara 26-29 ppt, kecepatan arus antara 0,035-0,04 cm/detik dan kecerahan antara 17,3-35,3 cm.

\section{Tipe Sedimen}

Jenis sedimen yang terdapat di perairan pantai Desa Api api tergolong tipe sedimen pasir berlumpur (Tabel 5). Ditemukannya sedimen pasir pada suatu wilayah penelitian ini diakibatkan oleh adanya pengaruh dari gelombang Selat Malaka yang membawa partikel-partikel sedimen pasir. Sementara untuk fraksi lumpur berasal dari vegetasi mangrove yang berada di perairan pantai Desa Api api. Sedimen yang dihasilkan dari proses erosi dan terbawa oleh aliran air akan diendapkan pada suatu tempat yang kecepatan alirannya melambat atau terhenti. Peristiwa pengendapan ini dikenal dengan proses sedimentasi. Proses ini berjalan sangat komplek, dimulai dari jatuhnya hujan yang menghasilkan energi kinetik sebagai permulaan dari proses erosi selanjutnya tanah menjadi partikel halus, lalu menggelinding bersama aliran, sebagian tertinggal di atas tanah sedangkan yang lain masuk ke sungai terbawa aliran menjadi angkutan sedimen.

Tabel 5. Jenis Sedimen pada Tiap Subzona Perairan Pantai Desa Api api.

\begin{tabular}{lccccc}
\hline \multirow{2}{*}{ Sedimen } & \multicolumn{5}{c}{ Subzona } \\
\cline { 2 - 6 } & 1 & 2 & 3 & 4 & 5 \\
\hline Kerikil (\%) & 0,00 & 0,00 & 0,00 & 0,00 & 0,00 \\
Pasir (\%) & 50,65 & 52,50 & 68,10 & 70,13 & 91,67 \\
Lumpur (\%) & 49,35 & 47,50 & 31,90 & 29,87 & 8,33 \\
Tipe & Pasir & Pasir & Pasir & Pasir & Pasir \\
\hline
\end{tabular}


Habitat kerang bambu berupa pasir berlumpur dengan arus air laut yang lemah. Kerang bambu bersembunyi atau menggali secara vertikal pada substrat berpasir dan sedikit keluar pada saat pasang surut. Kerang bambu banyak ditemukan di sepanjang perairan pantai dengan ciri pantai yang landai dan datar sehingga jika air laut surut jarak air dengan garis pantai dapat mencapai 200-300 m (Nurjanah et al., 2008).

Kerang bambu hidup di dalam substrat pada kedalaman $\pm 20 \mathrm{~cm}$. Hal ini berkaitan dengan ketersediaan makanan bagi kerang tersebut. Menurut Bahtiar (2012), bertambahnya kedalaman maka ketersediaan makanan menjadi faktor pembatas bagi fitoplankton yang menjadi makanan kerang muda (spat) sehingga kerang banyak tumbuh dekat permukaan air dan kerang menyukai perairan yang dangkal dengan kedalaman kurang dari 2 $\mathrm{m}$.

\section{Padatan Tersuspensi (TSS)}

Hasil analisis padatan tersuspensi pada tiap subzona di perairan Pantai Desa Api api dapat dilihat pada Tabel 6.

Tabel 6. Padatan Tersuspensi pada Tiap Subzona di Zona Intertidal Perairan Pantai Desa Api api.

\begin{tabular}{ccccc}
\hline \multirow{2}{*}{ Subzona } & \multicolumn{3}{c}{ Hasil perhitungan } & \multirow{2}{*}{ Nilai TSS (mg/l) } \\
\cline { 2 - 4 } & $\mathrm{A}(\mathrm{g})$ & $\mathrm{B}(\mathrm{g})$ & $\mathrm{V}(\mathrm{ml})$ & $\mathbf{3 8 6}$ \\
2 & 0,2184 & 0,1798 & 100 & $\mathbf{3 3 3}$ \\
3 & 0,1962 & 0,1659 & 100 & $\mathbf{2 5 1}$ \\
4 & 0,1963 & 0,1712 & 100 & $\mathbf{2 8 2}$ \\
5 & 0,1916 & 0,1634 & 100 & $\mathbf{1 3 0}$ \\
\hline
\end{tabular}

Padatan tersuspensi yang terdapat di perairan pantai Desa Api api berkisar 180$386 \mathrm{mg} / \mathrm{L}$. Nilai ini sangat tinggi jauh di atas standar baku mutu air laut menurut Keputusan Menteri Lingkungan Hidup No. 51 Tahun 2004 untuk biota laut yaitu $<80$ $\mathrm{mg} / \mathrm{L}$. Nilai TSS yang terlalu tinggi akan memberikan dampak buruk terhadap kualitas air karena akan mengurangi penetrasi cahaya matahari ke dalam badan air dan menyebabkan nilai kekeruhan yang tinggi sehingga dapat menggangu metabolisme biota.

\section{KESIMPULAN DAN SARAN}

Berdasarkan hasil penelitian dapat disimpulkan bahwa Kepadatan rata-rata kerang bambu di perairan pantai Desa Api api yaitu $3,12 \mathrm{ind} / \mathrm{m}^{2}$ pada bulan September dan 2,88 ind $/ \mathrm{m}^{2}$ pada bulan Oktober 2019.
Pola distribusi kerang bambu yang ada di zona intertidal perairan Desa Api api bersifat merata pada setiap subzona penelitian. Indeks kematangan gonad kerang bambu di perairan pantai Desa Api api yaitu berkisar di perairan pantai Desa Api api yaitu berkisar 2,28-8,60\% . Kemudian Tingkat kemantangan gonad yang paling banyak ditemukan pada bulan September yaitu TKG I sebanyak 6 individu, sementara pada bulan Oktober yaitu TKG III sebanyak 4 individu dan TKG IV sebanyak 3 individu.

Penelitian ini hanya dilakukan dalam interval waktu selama 2 bulan yaitu bulan September dan Oktober. Maka diharapkan untuk penelitian selanjutnya disarankan melakukan penelitian lanjutan pada bulan November hingga Desember kemudian bertahap dalam rentang waktu satu tahun 
supaya diketahui periode dan musim Kabupaten Bengkalis. pemijahan kerang bambu di Desa Api api

\section{DAFTAR PUSTAKA}

1. Ayache, N., L. Hmida, J. F. M. F Cardoso, Z. Haouas, F. D. Costa and M. S. Romdhane. (2016). Reproductive Cycle of the Razor Clam Solen marginatus (Pulteney, 1799) in the Southern Mediteranian Sea (Gulf of Gabes, South Tunisia). Journal of Shellfish Research, 35 (2) : 389-397.

2. Bahtiar. (2012). Kepadatan dan Distribusi Kerang Bulu (Anadara antiquata L, 1758) di perairan Wangi-wangi Selatan Desa Numana Kabupaten Wakatobi. Jurnal Manajemen Sumber Daya Perairan, 2(2): 113-122.

3. BPS [Badan Pusat Statistik] Kabupaten Bengkalis., (2017). BPS Kabupaten Bengkalis.

4. Effendi, M. I. (2002). Biologi Perikanan Bagian I. Studi Natural Histori. Institut Pertanian Bogor.

5. Efriyeldi., D.G. Bengen, R. Affandi dan T. Prartono. (2012). Perkembangan Gonad dan Musim Pemijahan Kerang Sepetang (Pharella acutidens) di Ekosistem Mangrove Dumai, Riau. IPB. Maspari Journal, 4(2): 137-147.

6. Inggriyani,Y.F., (2017). Analisis Kebiasaan makan Kerang Bambu (Solen lamarckii) di Perairan Pantai Desa Teluk Lancar Kecamatan Bantan Kabupaten Bengkalis Provinsi Riau. Jurnal Online Mahasiswa, 4 (1) : 38-41.

7. Litaay, M., E. Soekendarsi, A. G. M. Indaswari. (2015). Morfometri Kerang Tahu (Meretrix meretrix, Linaeus 1758) di Pasar Rakyat Makassar. Jurnal Biologi. 13 (2): 137-142.

8. Nurjanah, Kustiariyah dan S. Rusyadi. (2008). Karakteristik Gizi dan Potensi Pengembangan Kerang Bambu (Solen spp.) di Perairan Kabupaten Pamekasan, Madura. Jurnal Perikanan dan Kelautan, 13 (1):41-51.

9. Octavina, C., (2014). Aspek Pemanfaatan Sumberdaya Tiram Daging (Ostreidae) sebagai Upaya Pengelolaan Berbasis Struktur Populasi di Kuala Gigieng, Aceh Besar. Jurnal Agribisnis dan Perikanan, 4 (3) : 11-15.

10. Rifardi. (2008). Tekstur Sedimen: Sampling dan Analisis. Unri Press. Pekanbaru, 101 hlm

11. Sereflisan, H., S. Cek and M. Sereflisan. (2013). The Reproductive cycle of Potomida littoralis (Bivalvia: Unionidae) in Lake Golbasi, Turkey. Pakistan Journal Zoology, 45(5):1311-1319.

12. Subiyanto, A. Hartoko dan K. Umah. (2013). Struktur Sedimen dan Sebaran Kerang Pisau (Solen lamarckii) di Pantai Kejawanan Cirebon Jawa Barat. Journal of Management of Aquatic Resources, 2 (3): 65-73.

13. Takeuchi, S., Y. Ishi., K. Yoshikoshi., T. Takamasu., S. Nagae and A. Tamaki. (2017). Reproductive Cycle of Razor Clam Solen Grandis in Sasebo Bay, Kyushu, Japan. Journal of Shellfish Research, 36 (3): 577-578. 
14. Trisyani, N dan R. Nurul. (2008). Kandungan Nutrisi Lorjuk dari Pantai Timur Surabaya. Editor: Didik Hardianto dan M. Taufiqurrohman. Prosiding Seminar Nasional Kelautan IV, 24 April 2008, Universitas Hang Tuah. Surabaya.

15. Wahyuningtias, S. (2010). Analisis Biologi Reproduksi pada Kerang Darah (Anadara granosa) di Perairan Bojonegoro, Teluk Banten, Banten. Journal of Marine Research, 3(1): 35-40. 